\title{
PPO-Inhibiting Herbicides and Structurally Relevant Schiff Bases: Evaluation of Inhibitory Activities against Human Protoporphyrinogen Oxidase
}

\author{
Milan Jakubek 1,2,3 ${ }^{\mathbb{D}}$, Michal Masařík 1,2,4,5 , Tomáš Břiza 1,2,3, Robert Kaplánek 1,2,3(D), Kateřina Veselá 1,2,3, \\ Nikita Abramenko ${ }^{1}$ (i) and Pavel Martásek ${ }^{1, *}$
}

check for

updates

Citation: Jakubek, M.; Masařík, M.; Bříza, T.; Kaplánek, R.; Veselá, K.; Abramenko, N.; Martásek, P. PPOInhibiting Herbicides and Structurally Relevant Schiff Bases: Evaluation of Inhibitory Activities against Human Protoporphyrinogen Oxidase. Processes 2021, 9, 383 https://doi.org/10.3390/pr9020383

Academic Editor: Hoon Kim Received: 14 December 2020 Accepted: 12 February 2021 Published: 19 February 2021

Publisher's Note: MDPI stays neutral with regard to jurisdictional claims in published maps and institutional affiliations.

Copyright: (C) 2021 by the authors Licensee MDPI, Basel, Switzerland. This article is an open access article distributed under the terms and conditions of the Creative Commons Attribution (CC BY) license (https:// creativecommons.org/licenses/by/ $4.0 /)$
1 Department of Paediatrics and Inherited Metabolic Disorders, First Faculty of Medicine, Charles University and General University Hospital in Prague, 12108 Prague, Czech Republic; milan.jakubek@lf1.cuni.cz (M.J.); masarik@med.muni.cz (M.M.); tomas.briza@lf1.cuni.cz (T.B.); kaplanek@email.cz (R.K.); Katerina2.Vesela@vscht.cz (K.V.); nikita.abramenko@lf1.cuni.cz (N.A.)

2 BIOCEV, First Faculty of Medicine, Charles University, 25250 Vestec, Czech Republic

3 Department of Analytical Chemistry, Faculty of Chemical Engineering, University of Chemistry and Technology, 16628 Prague, Czech Republic

4 Department of Physiology, Faculty of Medicine, Masaryk University, Kamenice 5, 62500 Brno, Czech Republic

5 Department of Pathological Physiology, Faculty of Medicine, Masaryk University, Kamenice 5, 62500 Brno, Czech Republic

* Correspondence: pavel.martasek@lf1.cuni.cz

Abstract: The study of human protoporphyrinogen oxidase (hPPO) inhibition can contribute significantly to a better understanding of some pathogeneses (e.g., porphyria, herbicide exposure) and the development of anticancer agents. Therefore, we prepared new potential inhibitors with Schiff base structural motifs (2-hydroxybenzaldehyde-based Schiff bases 9-13 and chromanone derivatives 17-19) as structurally relevant to PPO herbicides. The inhibitory activities (represented by the half maximal inhibitory concentration ( $\mathrm{IC}_{50}$ ) values) and enzymatic interactions (represented by the $\mathrm{hPPO}$ melting temperatures) of these synthetic compounds and commercial PPO herbicides used against hPPO were studied by a protoporphyrin IX fluorescence assay. In the case of PPO herbicides, significant hPPO inhibition and changes in melting temperature were observed for oxyfluorten, oxadiazon, lactofen, butafenacil, saflufenacil, oxadiargyl, chlornitrofen, and especially fomesafen. Nevertheless, the prepared compounds did not display significant inhibitory activity or changes in the hPPO melting temperature. However, a designed model of hPPO inhibitors based on the determined $\mathrm{IC}_{50}$ values and a docking study (by using AutoDock) found important parts of the herbicide structural motif for hPPO inhibition. This model could be used to better predict PPO herbicidal toxicity and improve the design of synthetic inhibitors.

Keywords: protoporphyrinogen oxidase; inhibitors; herbicides

\section{Introduction}

Porphyrias are very rare diseases associated with abnormal haem production that lead to the accumulation of porphyrins or their precursors within the liver and other organs [1,2]. Variegate porphyria is caused by mutations to protoporphyrinogen oxidase (PPO, EC 1.3.3.4) and subsequent activity loss. This enzyme catalyzes the oxygen-dependent sixelectron oxidation of protoporphyrinogen IX to protoporphyrin IX [3-5]. During acute attacks, patients display abnormal skin reactions to sunlight due to reactive singlet oxygen formation and oxidative stress following photooxidation, mainly in the liver [6,7]. Patients with variegate porphyria can have a significantly higher risk of liver cancer $[6,8]$.

This phenomenon can also be caused by various toxic agents, such as some herbicides $[9,10]$. Using herbicides is one of the most commonly used methods to control weeds 
and preserve crop quality and yield. During the last 30 years, numerous structurally diverse PPO-inhibiting herbicides have been developed and commercialized, such as diphenyl ethers and thiadiazoles [11]. In contrast to herbicides with other modes of action, the application of these classes of herbicides displays some important benefits, such as a low use rate, broad-spectrum herbicidal activity, a quick onset of action, long-lasting effects, and environmentally friendly side effects. Nevertheless, the display of serious toxic effects to animals and humans after exposure to these compounds, especially long-term exposure, cannot be excluded.

At present, some influencing work has implied that these herbicide types also display serious inhibitory effects on human protoporphyrinogen IX oxidase (hPPO) [12] due to porphyrin accumulation in hepatocytes [13]. Butafenacil has long been used as an antiPPO herbicide. It is expected that some of its toxicity is caused by inhibition of animal PPOs $[14,15]$. For example, a published study by Leet et al. stated that exposure of zebrafish embryos to butafenacil led to porphyria symptoms, such as porphyrin accumulation [14]. After fomesafen application, higher levels of reactive oxygen species (ROS), weaker immune systems, and reduced numbers of white cells were observed [16]. In a mouse model, a specific dosage caused porphyria syndrome, as evidenced by liver porphyrin accumulation $[17,18]$. Similarly, oxyfluorfen and oxadiazon treatment have led to higher porphyrin accumulation in rat hepatocytes and mouse livers. These phenomena were associated with decreased PPO activity; however, the inhibition activity (represent by its $\mathrm{IC}_{50}$ values) for these herbicides have not yet been determined.

BaR-2 has displayed significantly higher inhibitory activity against PPO than commercially used herbicides [19]. Nevertheless, its inhibitory activity has not yet been determined for human or mammalian PPOs. The above strongly implies that detailed quantification of their inhibitory effects on PPOs (represented by $\mathrm{IC}_{50}$ values) could precisely predict the toxicity of these compounds in humans and animals.

In addition, obtaining this information could also be useful for the design of new pharmacophores targeting PPOs for the treatment of oncological diseases. Relevant work found that PPOs are overexpressed in some cancer types (e.g., colorectal cancer) [20]. Targeting PPO could be a promising way to enhance photodynamic activity based on the application of 5-aminolevulinic acid [21-23]. However, prospective strategies for the preparation of anticancer agents could combine additional structural motifs, such as Schiff bases, for their molecular design.

Schiff bases possess a wide range of biological activities, including the repression of oncological processes and signaling pathways [24-26]. Schiff bases bearing 2-hydroxyaryl moieties can bind arginine groups [27] and thereby possibly target Arg-98 or Arg-59, which are key amino acids that maintain PPO activity $[28,29]$. Combining this structural motif with polychlorinated phenyls (for a possible interaction with Met-368 of PPO) [29] could lead to the design of new types of hPPO inhibitors. These compounds are structurally relevant to known PPO herbicides. Thus, we prepared two sets of potential inhibitors: 2-hydroxybenzaldehyde-based Schiff bases and chromanone derivatives. Moreover, Schiff bases bearing 2-hydroxyaryl moieties can bind metal ions and thereby expand their anticancer effects [30-33].

In this work, we decided to study the influence of PPO herbicides and novel PPO inhibitors based on the Schiff base structural motif on hPPO activity. Both sets of compounds could represent new structural motifs for novel anticancer agents. In the case of PPO herbicides, the obtained results could also be used for better environmental risk prediction.

\section{Materials and Methods}

\subsection{Measurements and Materials}

All chemicals and solvents were purchased from commercial suppliers (Sigma-Aldrich, Santiago Chemicals and TCI Europe) and were used without further purification. Nuclear magnetic resonance (NMR) spectra were recorded on a $500 \mathrm{MHz}$ instrument at room temperature $\left(\sim 25^{\circ} \mathrm{C}\right)$ in dimethyl sulfoxide (DMSO)- $d_{6}$. The chemical shifts $(\delta)$ are presented 
in ppm and coupling constants $(J)$ are presented in Hz. The program MestReNova ver. 14.1 was used to process the NMR spectra. High-resolution mass spectrometry (HRMS) spectra were obtained using electrospray ionization (ESI) with a triple quadrupole mass spectrometer (TSQ Quantum Access) and an LTQ Orbitrap spectrometer. ${ }^{1} \mathrm{H}$ and ${ }^{13} \mathrm{C}$ NMR spectra of prepared compounds are shown in Supplementary Figures S1-S10.

\subsection{Preparation of Ethyl 2-(2,4-Dichloro-5-nitrophenoxy)acetate (2)}

2,4-Dichloro-5-nitrophenol (1; $1040 \mathrm{mg} ; 5 \mathrm{mmol})$ and potassium carbonate (1382 $\mathrm{mg}$; $10 \mathrm{mmol})$ were mixed in anhydrous dimethylformamide $(15 \mathrm{~mL})$. The mixture was stirred at $25{ }^{\circ} \mathrm{C}$ for $15 \mathrm{~min}$, and ethyl bromoacetate $(0.9 \mathrm{~mL} ; 8 \mathrm{mmol})$ was added. This reaction mixture was stirred at $60{ }^{\circ} \mathrm{C}$ overnight. Then, water $(100 \mathrm{~mL})$ was added, and the mixture was extracted with ethyl acetate $(2 \times 100 \mathrm{~mL})$. The organic fraction was then washed with water $(2 \times 75 \mathrm{~mL})$ and brine $(75 \mathrm{~mL})$, dried over sodium sulfate, and evaporated to dryness. The crude product was purified by column chromatography on silica, eluent: dichloromethane. Ethyl 2-(2,4-dichloro-5-nitrophenoxy)acetate (2) was obtained with a yield of $1326 \mathrm{mg}(90 \%)$ as a white wax.

${ }^{1} \mathrm{H}$ NMR: $1.21(\mathrm{t}, J=7.0 \mathrm{~Hz}, 3 \mathrm{H}) ; 4.18(\mathrm{q}, J=7.0 \mathrm{~Hz}, 2 \mathrm{H}) ; 5.06(\mathrm{~s}, 2 \mathrm{H}) ; 7.96(\mathrm{~s}, 1 \mathrm{H}) ; 8.03$ (s, 1H). ${ }^{13} \mathrm{C}$ NMR: 14.0, 61.0, 66.0, 110.7, 117.1, 126.6, 131.9, 146.6, 152.6, 167.6 ppm. HRMS $\left(\mathrm{ACPI}^{-}\right)$calcd for $\mathrm{C}_{10} \mathrm{H}_{9} \mathrm{C}_{12} \mathrm{NO}_{5}[\mathrm{M}]^{-}:$292.98578, found: 292.98651.

\subsection{Preparation of Ethyl 2-(5-Amino-2,4-dichlorophenoxy)acetate (3)}

Ethyl 2-(2,4-dichloro-5-nitrophenoxy)acetate (2; $1245 \mathrm{mg} ; 4.19 \mathrm{mmol})$ was dissolved in ethyl acetate $(75 \mathrm{~mL})$, and palladium on carbon $(10 \% ; 500 \mathrm{mg})$ was added. The reaction mixture was stirred under a hydrogen atmosphere (balloon) overnight. Then, the catalyst was filtered off and washed with ethyl acetate $(20 \mathrm{~mL})$. The solution was evaporated to dryness to give pure ethyl 2-(5-amino-2,4-dichlorophenoxy)acetate (3) with a yield of $1061 \mathrm{mg}(96 \%)$ as a yellowish wax.

${ }^{1} \mathrm{H}$ NMR: $1.22(\mathrm{t}, J=7.1 \mathrm{~Hz}, 3 \mathrm{H}) ; 4.18(\mathrm{q}, J=7.1 \mathrm{~Hz}, 2 \mathrm{H}) ; 4.73(\mathrm{~s}, 2 \mathrm{H}) ; 5.39$ (bs, 2H); 6.41 (s, 1H); 7.24 (s, 1H). ${ }^{13} \mathrm{C}$ NMR: 14.0, 60.8, 65.2, 100.1, 107.8, 109.2, 129.1, 144.6, 152.5, 168.1 ppm. HRMS $\left(\mathrm{ESI}^{+}\right)$calcd for $\mathrm{C}_{10} \mathrm{H}_{12} \mathrm{C}_{12} \mathrm{NO}_{3}\left[\mathrm{M}^{+} \mathrm{H}\right]^{+}:$264.01942, found: 264.01931 .

\subsection{Preparation of Schiff Base 9}

Ethyl-2-(5-amino-2,4-dichlorophenoxy)acetate (3; $53 \mathrm{mg} ; 0.2 \mathrm{mmol}$ ) and 2-hydroxy-3methoxybenzaldehyde $(4 ; 30 \mathrm{mg} ; 0.2 \mathrm{mmol})$ were dissolved in anhydrous ethanol $(10 \mathrm{~mL})$ and stirred at $75^{\circ} \mathrm{C}$ overnight. Orange precipitate formed almost immediately. After cooling, the solid product was filtered off, washed with ethanol $(30 \mathrm{~mL})$ and dried under vacuum. Ethyl-(E)-2-(2,4-dichloro-5-((2-hydroxy-3-methoxybenzylidene)amino)phenoxy)acetate (9) was obtained with a yield of $63 \mathrm{mg}(79 \%)$ as an orange solid.

${ }^{1} \mathrm{H}$ NMR: $1.22(\mathrm{t}, J=7.1 \mathrm{~Hz}, 3 \mathrm{H}) ; 3.83(\mathrm{~s}, 3 \mathrm{H}) ; 4.19(\mathrm{q}, J=7.1 \mathrm{~Hz}, 2 \mathrm{H}) ; 5.01(\mathrm{~s}, 2 \mathrm{H}) ; 6.96$ $(\mathrm{t}, J=7.9 \mathrm{~Hz}, 1 \mathrm{H}) ; 7.19(\mathrm{dd}, J=8.1,1.4 \mathrm{~Hz}, 1 \mathrm{H}) ; 7.24(\mathrm{dd}, J=7.9,1.4 \mathrm{~Hz}, 1 \mathrm{H}) ; 7.43(\mathrm{~s}, 1 \mathrm{H})$; 7.77 (s, 1H); 9.03 (s, 1H); 12.99 (s, 1H). ${ }^{13}$ C NMR: 14.0, 55.9, 60.8, 65.6, 105.4, 116.2, 118.9, 120.2, 120.6, 124.0, 130.1, 144.0, 148.0, 150.7, 152.9, 165.3, 167.9 ppm. HRMS $\left(\mathrm{ESI}^{+}\right)$calcd for $\mathrm{C}_{18} \mathrm{H}_{18} \mathrm{Cl}_{2} \mathrm{NO}_{5}\left[\mathrm{M}^{+} \mathrm{H}\right]^{+}:$398.05620, found: 398.05652.

\subsection{Preparation of Schiff Base $\mathbf{1 0}$}

Ethyl-2-(5-amino-2,4-dichlorophenoxy)acetate (3; $53 \mathrm{mg} ; 0.2 \mathrm{mmol}$ ) and 2-hydroxy-4methylbenzaldehyde (5; $27 \mathrm{mg} ; 0.2 \mathrm{mmol})$ were dissolved in anhydrous ethanol $(10 \mathrm{~mL})$ and stirred at $75{ }^{\circ} \mathrm{C}$ overnight. A yellowish solid gradually precipitated out of solution. After cooling, the solid product was filtered off, washed with ethanol $(30 \mathrm{~mL})$ and dried under vacuum. Ethyl-(E)-2-(2,4-dichloro-5-((2-hydroxy-4-methylbenzylidene)amino)phenoxy)acetate (10) was obtained with a yield of $57 \mathrm{mg}(75 \%)$ as a pale-yellow solid.

${ }^{1} \mathrm{H}$ NMR: 1.22 (t, $\left.J=7.1 \mathrm{~Hz}, 3 \mathrm{H}\right) ; 2.39$ (s, 3H); 4.19 (q, J = 7.1 Hz, 2H); $5.02(\mathrm{~s}, 2 \mathrm{H}) ; 6.85$ $(\mathrm{s}, 1 \mathrm{H}) ; 6.85(\mathrm{~d}, J=8.0 \mathrm{~Hz}, 1 \mathrm{H}) ; 7.39(\mathrm{~s}, 1 \mathrm{H}) ; 7.52(\mathrm{~d}, J=8.0 \mathrm{~Hz}, 1 \mathrm{H}) ; 7.74(\mathrm{~s}, 1 \mathrm{H}) ; 8.95(\mathrm{~s}, 1 \mathrm{H})$; 12.93 (s, 1H). ${ }^{13} \mathrm{C}$ NMR: 14.0, 21.5, 60.8, 65.6, 105.3, 116.7, 117.1, 119.9, 120.5, 120.6, 130.1, 
132.7, 144.2, 145.0, 152.9, 160.6, 164.8, 167.9 ppm. HRMS (ESI ${ }^{+}$) calcd for $\mathrm{C}_{18} \mathrm{H}_{18} \mathrm{C}_{12} \mathrm{NO}_{4}$ $\left[\mathrm{M}^{+} \mathrm{H}\right]^{+}:$382.06129, found: 382.06137 .

\subsection{Preparation of Schiff Base $\mathbf{1 1}$}

Ethyl-2-(5-amino-2,4-dichlorophenoxy)acetate (3; $53 \mathrm{mg} ; 0.2 \mathrm{mmol}$ ) and 5-chloro-2hydroxybenzaldehyde $(6 ; 28 \mathrm{mg} ; 0.2 \mathrm{mmol})$ were dissolved in anhydrous ethanol $(10 \mathrm{~mL})$ and stirred at $75{ }^{\circ} \mathrm{C}$ overnight. A yellowish solid gradually precipitated out of solution. After cooling, the solid product was filtered off, washed with ethanol $(30 \mathrm{~mL})$ and dried under vacuum. Ethyl-(E)-2-(2,4-dichloro-5-((5-chloro-2-hydroxybenzylidene)amino)phenoxy)acetate (11) was obtained with a yield of $65 \mathrm{mg}(79 \%)$ as a pale-yellow solid.

${ }^{1} \mathrm{H}$ NMR: $1.22(\mathrm{t}, J=7.1 \mathrm{~Hz}, 3 \mathrm{H}) ; 4.19(\mathrm{q}, J=7.1 \mathrm{~Hz}, 2 \mathrm{H}) ; 5.01(\mathrm{~s}, 2 \mathrm{H}) ; 7.04(\mathrm{~d}, J=8.8 \mathrm{~Hz}$, $1 \mathrm{H}) ; 7.37(\mathrm{~s}, 1 \mathrm{H}) ; 7.50(\mathrm{dd}, J=8.8,2.7 \mathrm{~Hz}, 1 \mathrm{H}) ; 7.72(\mathrm{~d}, J=2.7 \mathrm{~Hz}, 1 \mathrm{H}) ; 7.76(\mathrm{~s}, 1 \mathrm{H}) ; 8.95(\mathrm{~s}$, 1H); 12.78 (s, 1H). ${ }^{13} \mathrm{C}$ NMR: 14.0, 60.9, 65.6, 105.4, 118.9, 120.4, 120.6, 122.7, 130.2, 131.0, $133.5,144.2,152.9,159.0,163.6,167.8$ ppm. HRMS $\left(\right.$ ESI $\left.^{+}\right)$calcd for $\mathrm{C}_{17} \mathrm{H}_{15} \mathrm{C}_{13} \mathrm{NO}_{4}\left[\mathrm{M}^{+} \mathrm{H}\right]^{+}$: 402.00667, found: 402.00641 .

\subsection{Preparation of Schiff Base $\mathbf{1 2}$}

Ethyl-2-(5-amino-2,4-dichlorophenoxy)acetate (3; $53 \mathrm{mg} ; 0.2 \mathrm{mmol}$ ) and 2,5-hydroxybenzaldehyde $(7 ; 28 \mathrm{mg} ; 0.2 \mathrm{mmol})$ were dissolved in anhydrous ethanol $(10 \mathrm{~mL})$ and stirred at $75{ }^{\circ} \mathrm{C}$ overnight. After cooling, the dark yellow solution was concentrated under reduced pressure to approximately half the volume, and water $(10 \mathrm{~mL})$ was added. The yellow precipitate was filtered off, washed with an ethanol-water mixture $(1: 2 \mathrm{v} / \mathrm{v}, 30 \mathrm{~mL})$ and dried under vacuum. Ethyl-(E)-2-(2,4-dichloro-5-((2,5-dihydroxybenzylidene)amino)phenoxy)acetate (12) was obtained with a yield of $63 \mathrm{mg}(88 \%)$ as a yellow solid.

${ }^{1} \mathrm{H}$ NMR: $1.23(\mathrm{t}, J=7.1 \mathrm{~Hz}, 3 \mathrm{H}) ; 4.19(\mathrm{q}, J=7.1 \mathrm{~Hz}, 2 \mathrm{H}) ; 5.02(\mathrm{~s}, 2 \mathrm{H}) ; 6.83(\mathrm{~d}, J=$ $8.8 \mathrm{~Hz}, 1 \mathrm{H}) ; 6.92(\mathrm{dd}, J=8.8,3.0 \mathrm{~Hz}, 1 \mathrm{H}) ; 7.03(\mathrm{~d}, J=3.0 \mathrm{~Hz}, 1 \mathrm{H}) ; 7.42(\mathrm{~s}, 1 \mathrm{H}) ; 7.77(\mathrm{~s}, 1 \mathrm{H})$; $8.87(\mathrm{~s}, 1 \mathrm{H}) ; 9.40(\mathrm{~s}, 1 \mathrm{H}) ; 12.23(\mathrm{~s}, 1 \mathrm{H}) .{ }^{13} \mathrm{C}$ NMR: 14.0, 60.8, 65.6, 105.4, 116.8, 117.5, 119.0, $119.9,120.5,122.2,130.1,144.7,149.7,152.9,153.4,164.8,167.9$ ppm. HRMS $\left(\mathrm{ESI}^{+}\right)$calcd for $\mathrm{C}_{17} \mathrm{H}_{16} \mathrm{C}_{12} \mathrm{NO}_{5}\left[\mathrm{M}^{+} \mathrm{H}\right]^{+}:$384.04055, found: 384.04102 .

\subsection{Preparation of Schiff Base $\mathbf{1 3}$}

Ethyl-2-(5-amino-2,4-dichlorophenoxy)acetate (3; $53 \mathrm{mg} ; 0.2 \mathrm{mmol}$ ) and 2-hydroxy-1naphthaldehyde $(8 ; 35 \mathrm{mg} ; 0.2 \mathrm{mmol})$ were dissolved in anhydrous ethanol $(10 \mathrm{~mL})$ and stirred at $75{ }^{\circ} \mathrm{C}$ overnight. Yellow precipitate formed almost immediately. After cooling, the solid product was filtered off, washed with ethanol $(30 \mathrm{~mL})$ and dried under vacuum. Ethyl(E)-2-(2,4-dichloro-5-(((2-hydroxynaphthalen-1-yl)methylene)amino)phenoxy)acetate (13) was obtained with a yield of $77 \mathrm{mg}(92 \%)$ as a yellow solid.

${ }^{1} \mathrm{H}$ NMR: $1.24(\mathrm{t}, J=7.1 \mathrm{~Hz}, 3 \mathrm{H}) ; 4.22(\mathrm{q}, J=7.1 \mathrm{~Hz}, 2 \mathrm{H}) ; 5.15(\mathrm{~s}, 2 \mathrm{H}) ; 7.13(\mathrm{~d}, J=9.1 \mathrm{~Hz}$, $1 \mathrm{H}) ; 7.43(\mathrm{t}, J=7.6 \mathrm{~Hz}, 1 \mathrm{H}) ; 7.63(\mathrm{t}, J=7.8 \mathrm{~Hz}, 1 \mathrm{H}) ; 7.72(\mathrm{~s}, 1 \mathrm{H}) ; 7.79(\mathrm{~s}, 1 \mathrm{H}) ; 7.87(\mathrm{~d}, J=$ $8.0 \mathrm{~Hz}, 1 \mathrm{H}) ; 8.03(\mathrm{~d}, J=9.1 \mathrm{~Hz}, 1 \mathrm{H}) ; 8.54(\mathrm{~d}, J=8.4 \mathrm{~Hz}, 1 \mathrm{H}) ; 9.72(\mathrm{~s}, 1 \mathrm{H}) ; 15.50(\mathrm{~s}, 1 \mathrm{H}) .{ }^{13} \mathrm{C}$ NMR: 14.0, 60.8, 65.8, 105.2, 109.2, 119.5, 119.8, 120.7, 120.8, 123.9, 127.1, 128.2, 129.1, 130.1, 132.7, 137.0, 141.9, 153.0, 158.4, 167.3, 167.9 ppm. HRMS (ESI ${ }^{+}$) calcd for $\mathrm{C}_{21} \mathrm{H}_{18} \mathrm{C}_{12} \mathrm{NO}_{4}$ $\left[\mathrm{M}^{+} \mathrm{H}\right]^{+}:$418.06129, found: 418.06126 .

\subsection{Preparation of Chromanone $\mathbf{1 7}$}

Ethyl-2-(5-amino-2,4-dichlorophenoxy)acetate (3; $53 \mathrm{mg} ; 0.2 \mathrm{mmol}$ ) and 3-formylchromone $(\mathbf{1 4} ; 35 \mathrm{mg} ; 0.2 \mathrm{mmol})$ were dissolved in anhydrous isopropanol $(8 \mathrm{~mL})$ and stirred at $75^{\circ} \mathrm{C}$ overnight. Then, the reaction mixture was evaporated to dryness, and diethyl ether $(10 \mathrm{~mL})$ was added followed by hexane $(10 \mathrm{~mL})$. The solid product was filtered off, washed with a diethyl ether-hexane mixture $(1: 1 v / v, 20 \mathrm{~mL})$ and dried under vacuum. Ethyl-(Z)-2(2,4-dichloro-5-(((2-isopropoxy-4-oxochroman-3-ylidene)methyl)amino)phenoxy)acetate (17) was obtained with a yield of $63 \mathrm{mg}(66 \%)$ as a pale-yellow solid.

${ }^{1} \mathrm{H}$ NMR: $1.04(\mathrm{~d}, J=6.2 \mathrm{~Hz}, 3 \mathrm{H}) ; 1.20(\mathrm{~d}, J=6.1 \mathrm{~Hz}, 3 \mathrm{H}) ; 1.23(\mathrm{t}, J=7.1 \mathrm{~Hz}, 3 \mathrm{H}) ; 4.12$ (hept, $J=6.1 \mathrm{~Hz}, 1 \mathrm{H}) ; 4.20(\mathrm{q}, J=7.1 \mathrm{~Hz}, 2 \mathrm{H}) ; 5.02(\mathrm{~s}, 2 \mathrm{H}) ; 6.01(\mathrm{~s}, 1 \mathrm{H}) ; 7.08(\mathrm{~d}, J=8.1 \mathrm{~Hz}$, 
$1 \mathrm{H}), 7.14(\mathrm{t}, J=7.5 \mathrm{~Hz}, 1 \mathrm{H}) ; 7.38(\mathrm{~s}, 1 \mathrm{H}) ; 7.56(\mathrm{~m}, 1 \mathrm{H}) ; 7.74(\mathrm{~s}, 1 \mathrm{H}) ; 7.87(\mathrm{~m}, 1 \mathrm{H}) ; 8.16(\mathrm{~d}, J=$ $11.9 \mathrm{~Hz}, 1 \mathrm{H}) ; 12.21(\mathrm{~d}, J=11.9 \mathrm{~Hz}, 1 \mathrm{H}) .{ }^{13} \mathrm{C}$ NMR: $14.0,22.1,23.2,60.8,65.8,70.0,98.6,101.2$, $105.9,113.3,116.3,118.1,122.0,122.2,125.9,130.2,135.0,136.1,143.2,153.1,155.8,167.7$, 181.1 ppm. HRMS (ACPI ${ }^{-}$) calcd for $\mathrm{C}_{23} \mathrm{H}_{22} \mathrm{Cl}_{2} \mathrm{NO}_{6}[\mathrm{M}-\mathrm{H}]^{-}: 478.08242$, found: 478.08345 .

\subsection{Preparation of Chromanone $\mathbf{1 8}$}

Ethyl-2-(5-amino-2,4-dichlorophenoxy)acetate (3; $53 \mathrm{mg} ; 0.2 \mathrm{mmol}$ ) and 6-fluoro-3formylchromone $(\mathbf{1 5} ; 38 \mathrm{mg} ; 0.2 \mathrm{mmol})$ were dissolved in anhydrous isopropanol $(8 \mathrm{~mL})$ and stirred at $75{ }^{\circ} \mathrm{C}$ overnight. A yellow solid gradually precipitated out of the solution. After cooling, the solid product was filtered off, washed with isopropanol $(20 \mathrm{~mL})$ and dried under vacuum. Ethyl-(Z)-2-(2,4-dichloro-5-(((6-fluoro-2-isopropoxy-4-oxochroman-3ylidene)methyl)amino)phenoxy)acetate (18) was obtained with a yield of $69 \mathrm{mg}(69 \%)$ as a yellow solid.

${ }^{1} \mathrm{H}$ NMR: $1.04(\mathrm{~d}, J=6.2 \mathrm{~Hz}, 3 \mathrm{H}) ; 1.20(\mathrm{~d}, J=6.1 \mathrm{~Hz}, 3 \mathrm{H}) ; 1.23(\mathrm{t}, J=7.1 \mathrm{~Hz}, 3 \mathrm{H}) ; 4.11$ (hept, $J=6.1 \mathrm{~Hz}, 1 \mathrm{H}) ; 4.20(\mathrm{q}, J=7.1 \mathrm{~Hz}, 2 \mathrm{H}) ; 5.02(\mathrm{~s}, 2 \mathrm{H}) ; 6.02(\mathrm{~s}, 1 \mathrm{H}) ; 7.15(\mathrm{dd}, J=8.9$, $4.2 \mathrm{~Hz}, 1 \mathrm{H}) ; 7.39$ (s, 1H); $7.44(\mathrm{td}, J=8.7,3.1 \mathrm{~Hz}, 1 \mathrm{H}) ; 7.57(\mathrm{dd}, J=8.5,3.1 \mathrm{~Hz}, 1 \mathrm{H}) ; 7.75$ $(\mathrm{s}, 1 \mathrm{H}) ; 8.21(\mathrm{~d}, J=11.9 \mathrm{~Hz}, 1 \mathrm{H}) ; 12.20(\mathrm{~d}, J=12.0 \mathrm{~Hz}, 1 \mathrm{H}) .{ }^{13} \mathrm{C}$ NMR: 14.0, 22.1, 23.1, 60.8, 65.8, 70.1, 98.6, 101.4, 105.5, $111.1(\mathrm{~d}, J=24.0 \mathrm{~Hz}), 113.4,116.6,120.1(\mathrm{~d}, J=7.8 \mathrm{~Hz}), 122.1(\mathrm{~d}$, $J=24 \mathrm{~Hz}), 123.0(\mathrm{~d}, J=6.6 \mathrm{~Hz}), 130.3,135.9,143.9,151.9(\mathrm{~d}, J=1.5 \mathrm{~Hz}), 153.1,157.0(\mathrm{~d}, J=$ 239.2 Hz), 167.7, 180.1 ppm. HRMS $\left(\mathrm{ACPI}^{-}\right)$calcd for $\mathrm{C}_{23} \mathrm{H}_{21} \mathrm{Cl}_{2} \mathrm{FNO}_{6}[\mathrm{M}-\mathrm{H}]^{-}$: 496.07300, found: 496.07404 .

\subsection{Preparation of Chromanone 19}

Ethyl-2-(5-amino-2,4-dichlorophenoxy)acetate (3; $53 \mathrm{mg} ; 0.2 \mathrm{mmol}$ ) and 6-nitro-3formylchromone $(\mathbf{1 6} ; 44 \mathrm{mg} ; 0.2 \mathrm{mmol})$ were dissolved in anhydrous isopropanol $(8 \mathrm{~mL})$ and stirred at $75{ }^{\circ} \mathrm{C}$ overnight. A yellow solid gradually precipitated out of solution. After cooling, the solid product was filtered off, washed with isopropanol $(20 \mathrm{~mL})$ and dried under vacuum. Ethyl-(Z)-2-(2,4-dichloro-5-((2-isopropoxy-6-nitro-4-oxochroman-3ylidene)methyl)amino)phenoxy)acetate (19) was obtained with a yield of $98 \mathrm{mg}(93 \%)$ as a yellow solid.

${ }^{1} \mathrm{H}$ NMR: $1.07(\mathrm{~d}, J=6.2 \mathrm{~Hz}, 3 \mathrm{H}) ; 1.20(\mathrm{~d}, J=6.4 \mathrm{~Hz}, 3 \mathrm{H}) ; 1.24(\mathrm{t}, J=7.1 \mathrm{~Hz}, 3 \mathrm{H}) ; 4.19$ $(\mathrm{m}, 3 \mathrm{H}) ; 5.03(\mathrm{~s}, 2 \mathrm{H}) ; 6.19(\mathrm{~s}, 1 \mathrm{H}) ; 7.36(\mathrm{~d}, J=9.0 \mathrm{~Hz}, 1 \mathrm{H}) ; 7.42(\mathrm{~s}, 1 \mathrm{H}) ; 7.82(\mathrm{~s}, 1 \mathrm{H}) ; 8.31(\mathrm{~d}$, $J=12.0 \mathrm{~Hz}, 1 \mathrm{H}) ; 8.40(\mathrm{dd}, J=9.0,2.8 \mathrm{~Hz}, 1 \mathrm{H}) ; 8.63(\mathrm{~d}, J=2.8 \mathrm{~Hz}, 1 \mathrm{H}) ; 12.26(\mathrm{~d}, J=12.2 \mathrm{~Hz}$, 1H). ${ }^{13}$ C NMR: 14.0, 22.1, 23.1, 60.9, 65.8, 70.9, 99.7, 101.6, 104.8, 113.7, 117.1, 119.7, 121.6, 122.0, 129.4, 130.3, 135.6, 142.1, 144.9, 153.1, 160.3, 167.6, 178.8 ppm. HRMS (ACPI ${ }^{-}$) calcd for $\mathrm{C}_{23} \mathrm{H}_{21} \mathrm{C}_{12} \mathrm{~N}_{2} \mathrm{O}_{8}[\mathrm{M}-\mathrm{H}]^{-}$: 523.06750, found: 523.06861 .

\subsection{Preparation of $B A R-2$}

Bar-2 was made according to Wang et al. [19].

\subsection{PPO Expression and Purification}

A plasmid for bacterial expression of human PPO (hPPO) was kindly provided by Dr. Harry A. Dailey (University of Georgia, Athens, GA, USA) [34]. For heterologous expression, E. coli JM109 cells were grown at $30{ }^{\circ} \mathrm{C}$ as reported previously [12,34]. Circle growth media was supplemented with riboflavin to a final concentration of $0.75 \mu \mathrm{g} / \mathrm{mL}$ for $2 \mathrm{~h}$ prior to harvesting. Cells were collected by centrifugation $(10,000 \times g, 10 \mathrm{~min})$, resuspended in breaking buffer $(50 \mathrm{mM}$ Tris $\mathrm{pH} \mathrm{8,} 100 \mathrm{mM} \mathrm{NaCl}, 10 \%$ glycerol, 0.5\% Tween $20(v / v)$ ) containing EDTA-free protease inhibitor cocktail (Roche Diagnostics $\mathrm{GmbH}$, Mannheim, Germany), sonicated on ice and centrifuged at $40,000 \times g$ for $30 \mathrm{~min}$. The supernatant was applied onto a Ni-NTA column (Ni-NTA Superflow, IBA, Germany), washed with 20 column volumes of equilibration buffer $(50 \mathrm{mM}$ Tris- $\mathrm{HCl}, 100 \mathrm{mM} \mathrm{NaCl}$, $30 \mathrm{mM}$ imidazole, $10 \%$ glycerol, $0.02 \%$ Tween $20, \mathrm{pH} 8$ ) and eluted with equilibration buffer supplemented with $300 \mathrm{mM}$ imidazole. The eluded fractions were pooled and concentrated. The final purification step encompassed size-exclusion chromatography on a Superdex 
200 16/60 column (GE Healthcare Life Sciences, Uppsala, Sweden) using $50 \mathrm{mM}$ Tris-HCl, $100 \mathrm{mM} \mathrm{NaCl}, 5 \%$ glycerol, and $0.02 \%$ Tween 80, pH 8.0, as the mobile phase.

\subsection{Inhibition Assay}

$\mathrm{IC}_{50}$ values were determined using a fluorescence-based assay quantifying an increase in fluorescence signal upon conversion of the non-fluorescent protoporphyrinogen IX to fluorescent protoporphyrin IX [12]. Briefly, PPO (final concentration $4 \mathrm{nM}$ ) was preincubated with a dilution series of tested inhibitors (concentration range $0.2-100 \mu \mathrm{M}$ ) in a 384-well plate in a total volume of $14 \mu \mathrm{L}$ for $10 \mathrm{~min}$ at $37^{\circ} \mathrm{C}$ in reaction buffer comprising $100 \mathrm{mM}$ $\mathrm{KH}_{2} \mathrm{HPO}_{4}, 0.3 \%(w / v)$ Tween 80, 5 mM DTT, and $1 \mathrm{mM}$ EDTA, pH 7.2. Reactions were initiated by the addition of $7 \mu \mathrm{L}$ of $10 \mu \mathrm{M}$ protoporphyrinogen IX into the PPO/inhibitor mixture. The fluorescence signal of protoporphyrin IX was monitored with a CLARIOstar fluorimeter (BMG Labtech $\mathrm{GmbH}$, Ortenberg, Germany) at $\lambda_{\mathrm{EX}} / \lambda_{\mathrm{EM}}=410 / 632 \mathrm{~nm}$ using continuous readout mode at $37^{\circ} \mathrm{C}$ for $1 \mathrm{~h}$. The reaction velocity was calculated from the linear portion of the measured signal against a standard calibration curve of defined protoporphyrin IX concentrations. Non-linear regression analysis was employed to calculate the $\mathrm{IC}_{50}$ values using GraphPad Prism software [35]. Reactions without enzyme or inhibitor were used to define $0 \%$ and $100 \%$ PPO activity, respectively.

\subsection{Calculation of the Binding Energy of the PPO Complex with Schiff Bases}

Three-dimensional (3D) structural models for human protoporphyrinogen IX oxidase (hPPO) and for the orthologue from Nicotiana tabacum (ntPPO) were downloaded from the Protein Data Bank. 3D structural models of compounds $\mathbf{9}$ to 19 were drawn using MolView (https: / / molview.org, accessed on 19 May 2020), and the corresponding mol files containing 3D coordinates were generated. These files were converted to PDB format using NCI's online SMILES translator and structure file generator (https:/ / cactus.nci. nih.gov/translate/, accessed on 19 May 2020). For docking calculations, software from the AutoDock Vina suite was used [36]. The protein molecules were first placed in an orthorhombic box of suitable size for their total enclosure for the first round of docking calculations. Since the docking poses were found in the vicinity of the flavin adenine dinucleotide (FAD) isoalloxazine ring system, a second round of docking was performed using an orthorhombic box of size $20 \times 18 \times 22 \AA^{3}$ centered at a location on the accessible side of the isoalloxazine ring.

\subsection{Acifluorfen and Fomesafen Docking}

This docking simulation was performed with AutoDock Vina software [36] using the X-ray crystal structure of hPPO (3NKS, [37]). Ligand PDB files were prepared with the AceDRG stereochemical description generator [38]. The docking site was defined as a $30 \times 30 \times 30 \AA^{3}$ cube centered on the original co-crystallized ligand acifluorfen. Prior to the docking experiment, the docking workflow was validated by re-docking acifluorfen and comparing the calculated pose to the conformation of acifluorfen from the crystal structure. The re-docking results are shown in Supplementary Figure S11. The results of the docking experiment of acifluorfen and fomesafen were visualized and analyzed by PyMOL 2.4.1. [39].

\subsection{Viability Assay}

RPMI-8226 lymphoblasts were used to assess the cytotoxicity of the tested herbicides. Cells were diluted in $90 \mu \mathrm{L}$ of RPMI-1640 medium supplemented with $10 \%$ fetal bovine serum (FBS) to $2.5 \times 10^{5}$ cells $/ \mathrm{mL}$ in a 96 -well plate. Herbicides (50 mM stock solutions in dimethylsulfoxide (DMSO)) were diluted in PBS to $10 \times$ the desired concentration, and $10 \mu \mathrm{L}$ was added to the cells followed by incubation for 2 days at $37^{\circ} \mathrm{C}$. Following incubation, $10 \mu \mathrm{L}$ of (3-(4,5-dimethylthiazol-2-yl)-2,5-diphenyl tetrazolium bromide (MTT reagent) ( $5 \mathrm{mg} / \mathrm{mL}$ in PBS, Sigma-Aldrich) was added followed by incubation for $120 \mathrm{~min}$ at $37^{\circ} \mathrm{C}$. The metabolized formazan crystals were dissolved by the addition of $100 \mu \mathrm{L}$ of 
solubilization solution (40\% dimethyl formamide (DMF), $2 \%$ acetic acid, $16 \%$ SDS, $\mathrm{pH} 4.7$ ). Then, the absorbance at $570 \mathrm{~nm}$ was measured using a CLARIOstar plate reader (BMG Labtech), and data were plotted using GraphPad Prism software.

\subsection{8. hPPO Stability Determined by the ThermoFAD Assay}

The ThermoFAD stability assay according to Forneris et al. [40] was used to determine the melting temperature $\left(\mathrm{T}_{\mathrm{M}}\right)$ of the PPO complexes with the herbicides and Schiff bases. hPPO solution $(0.5 \mathrm{mg} / \mathrm{mL}$ final concentration) in $50 \mathrm{mM}$ Tris, $100 \mathrm{mM} \mathrm{NaCl}, 5 \%$ glycerol, and $0.2 \%$ Tween $20, \mathrm{pH} 8$, was incubated with/without $50 \mu \mathrm{M}$ herbicide in a total volume of $100 \mu \mathrm{L}$ for $15 \mathrm{~min}$ at room temperature. Samples were denatured using a RT-PCR cycler (CFX96-Touch, Bio-Rad, Hercules, CA, USA) with temperature ramping of $0.5{ }^{\circ} \mathrm{C}$ per step for $30 \mathrm{~s}$ from 20 to $95^{\circ} \mathrm{C}$. The fluorescence of the FAD cofactor was monitored using a 450-490 excitation filter and a 515-530 nm emission filter typically used for SYBR Greenbased RT-PCR. The maximum of the first derivative of the observed flavin fluorescence was taken as the apparent $T_{M}$.

\section{Results}

\subsection{Preparation and Characterization of Schiff Bases}

Two sets of target compounds were prepared by a three-step synthesis. In the first step, 2,4-dichloro-5-nitrophenol (1) was reacted with ethyl bromoacetate in the presence of $\mathrm{K}_{2} \mathrm{CO}_{3}$ in DMF at $60^{\circ} \mathrm{C}$. Ethyl 2-(2,4-dichloro-5-nitrophenoxy)acetate (2) was obtained in a yield of $90 \%$. In the next step, the nitro group of 2 was reduced with hydrogen with a palladium catalyst in ethyl acetate and the corresponding amine 3 was obtained in $96 \%$ yield. In the last step, amine 3 was reacted with different substituted 2-hydroxybenzaldehydes (4-8) in ethanol at $75^{\circ} \mathrm{C}$. These reactions gave corresponding Schiff bases 9-13 in yields of $75-92 \%$ (Scheme 1). The E-isomer was exclusively formed because it is stabilized by intramolecular hydrogen bonds (Figure 1). Thus, the ${ }^{1} \mathrm{H}$ NMR spectra showed only one singlet from the $-\mathrm{CH}=\mathrm{N}$ - hydrogen.
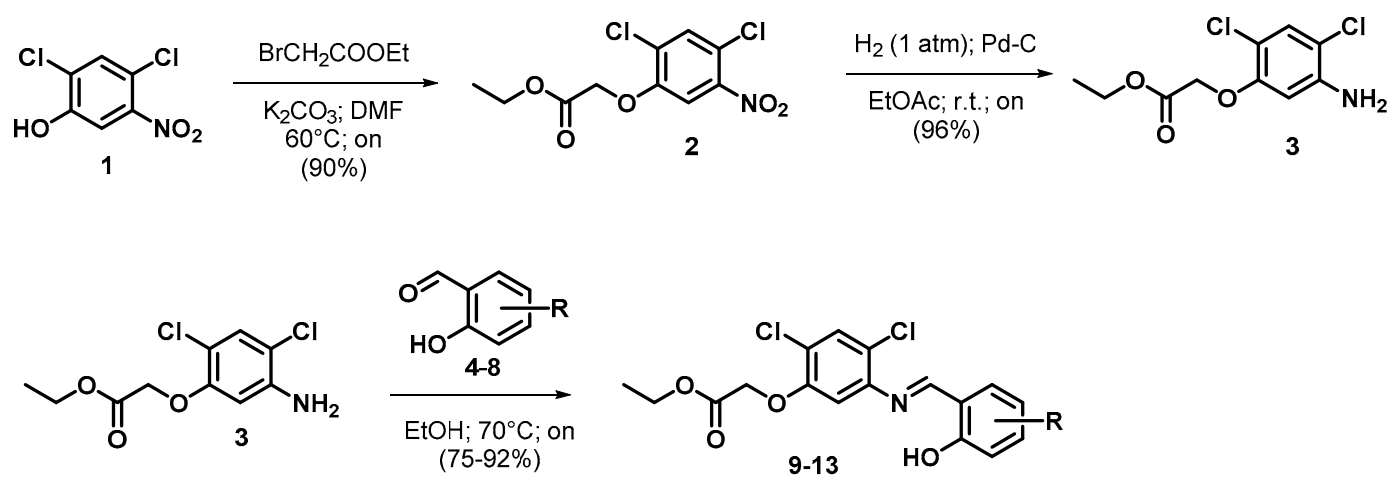

Scheme 1. Preparation of Schiff bases 9-13.
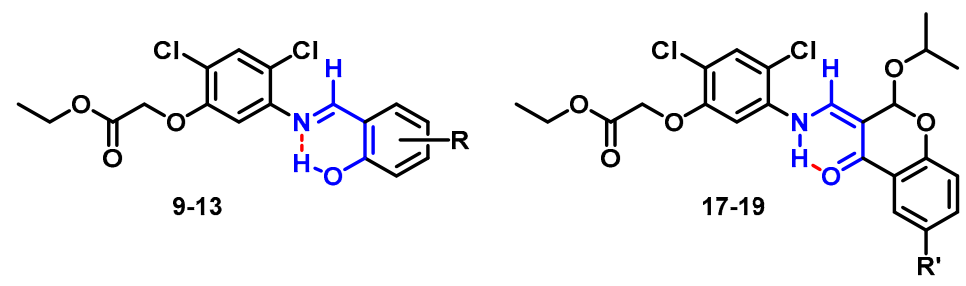

Figure 1. Intramolecular hydrogen bonds in Schiff bases 9-13 and chromanones 17-19.

Amine $\mathbf{3}$ was also reacted with substituted 3-formylchromones 14-16. The reaction of 3 -formylchromones with primary aromatic amines gives both Schiff base derivatives and 4-chromanone derivatives, depending on the solvent used [41-43]. In our case, we used isopropanol as the solvent; thus, we exclusively obtained the corresponding 4-chromanones 
17-19 in yields of 66-93\% (Scheme 2). The Z-isomer was exclusively formed because it is stabilized by intramolecular hydrogen bonds (Figure 1). Thus, the ${ }^{1} \mathrm{H}$ NMR spectra showed only one doublet from the $=\mathrm{CH}-\mathrm{N}$ - hydrogen.

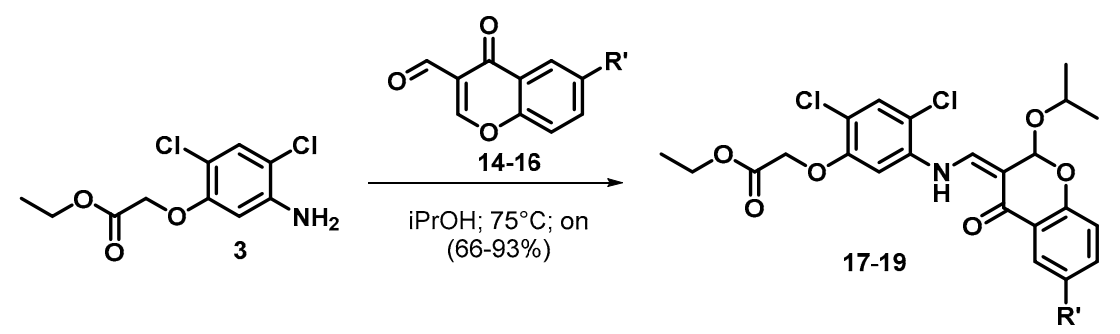

Scheme 2. Preparation of chromanones 17-19.

The structures of target compounds 9-13 and 17-19 and preparative yields are shown in Figure 2. The structures of the tested PPO herbicides are shown in Figure 3.<smiles>CCOC(=O)COc1cc(N=Cc2cccc(OC)c2O)c(Cl)cc1Cl</smiles><smiles>CCOC(=O)COc1cc(N=Cc2ccc(C)cc2O)c(Cl)cc1Cl</smiles><smiles>CCOC(=O)COc1cc(N=Cc2cc(Cl)ccc2O)c(Cl)cc1Cl</smiles><smiles>CCOC(=O)COc1cc(N=Cc2cc(O)ccc2O)c(Cl)cc1Cl</smiles><smiles>CCOC(=O)COc1cc(N=Cc2c(O)ccc3ccccc23)c(Cl)cc1Cl</smiles><smiles>CCOC(=O)COc1cc(N/C=C2\C(=O)c3ccccc3OC2OC(C)C)c(Cl)cc1Cl</smiles><smiles>CCOC(=O)COc1cc(N/C=C2/C(=O)C=C(F)C(C)=C2OC(C)C)c(Cl)cc1Cl</smiles><smiles>CCOC(=O)COc1cc(N/C=C2\C(=O)c3cc([N+](=O)[O-])ccc3OC2OC(C)C)c(Cl)cc1Cl</smiles>

Figure 2. Structures and preparative yields of 9-13 and 17-19.<smiles>CCOC(=O)C(C)OC(=O)c1cc(Oc2ccc(C(F)(F)F)cc2Cl)ccc1[N+](=O)[O-]</smiles><smiles>C=CCOC(=O)C(C)(C)OC(=O)c1cc(-n2c(=O)cc(C(F)(F)F)n(C)c2=O)ccc1Cl</smiles><smiles>CC(C)Oc1cc(-n2nc(C(C)(C)C)oc2=O)c(Cl)cc1Cl</smiles><smiles>C#CCOc1cc(-n2nc(C(C)(C)C)oc2=O)c(Cl)cc1Cl</smiles><smiles>COC(=O)C1(C)CC(c2cc(-n3c(=O)n(C)c(=S)n(C)c3=O)ccc2Cl)=NN1</smiles>

Figure 3. Structures of the tested commercial herbicides and Bar-2. 


\subsection{Determination of the Inhibitory Activities}

The $\mathrm{IC}_{50}$ values of the commercial herbicides (Figure 3) and prepared Schiff bases was determined by a fluorescence protoporphyrin IX assay. The results are shown in Table 1. Some of these compounds, such as oxyfluorten, lactofen, saflufenacil, fomesafen and chlornitrofen, displayed $\mathrm{IC}_{50}$ values in the submicromolar range. Nevertheless, for oxyfluorten, this value is comparable to published activities for plant PPOs [44]. In addition, the determined inhibitory concentrations of saflufenacil, lactofen and oxadiazon were significantly higher than the values published for plant PPOs [45-47], and their values are shown in Supplementary Table S1. For example, saflufenacil displayed nanomolar inhibitory activity against various plant PPOs [46]. Published values for lactofen $\left(\mathrm{IC}_{50}=\right.$ $25 \mathrm{nM}$ ) [45] and oxadiazon $\left(\mathrm{IC}_{50}=60 \mathrm{nM}\right)$ [47] are in the tens of nanomolar range; however, their inhibition activity against hPPO was significantly lower. Only fomesafen displayed an $\mathrm{IC}_{50}$ value against $\mathrm{hPPO}$ that was comparable to those of plant PPOs [44]. However, the value of fomesafen against $\mathrm{hPPO}(110 \mathrm{nM})$ strongly implies that fomesafen is a very potent inhibitor of mammalian PPOs. For example, the concentration of acifluorfen that elicits $50 \%$ of the total change in activity is $1.12 \mu \mathrm{M}$. Similarly, a value of $1.48 \mu \mathrm{M}$ was published by Shepherd et al. [12].

Table 1. $\mathrm{IC}_{50}$ values against hPPO for the tested inhibitors and meting temperatures for the hPPO inhibitor complexes.

\begin{tabular}{ccc}
\hline Compound & IC $_{\mathbf{5 0}}(\boldsymbol{\mu M})$ & $\mathbf{T}_{\mathbf{M}}\left({ }^{\circ} \mathbf{C}\right)^{\mathbf{1}}$ \\
\hline No inhibitor & $1.12 \pm 0.14$ & 48.5 \\
Acifluorfen & $>100$ & 58.5 \\
Chlortoluron & $0.13 \pm 0.06$ & 48.5 \\
Oxyfluorten & $1.92 \pm 0.39$ & 60.5 \\
Oxadiazon & $0.33 \pm 0.18$ & 57.5 \\
Lactofen & $0.15 \pm 0.05$ & 60.0 \\
Butafenacil & $0.25 \pm 0.02$ & 62.5 \\
Saflufenacil & $0.85 \pm 0.14$ & 60.5 \\
Oxadiargyl & $0.11 \pm 0.01$ & 58.0 \\
Fomesafen & $0.420 \pm 0.001$ & 61.5 \\
Chlornitrofen & $>100$ & 58.0 \\
Atrazine & $>100$ & 48.5 \\
Schiff base $\mathbf{9}$ & $>100$ & 48.5 \\
Schiff base 10 & $>100$ & 48.5 \\
Schiff base 11 & $>100$ & 48.5 \\
Schiff base 12 & $>100$ & 48.5 \\
Schiff base 13 & $>100$ & 48.5 \\
Chromone 17 & $>100$ & 48.5 \\
Chromone 18 & $>100$ & 48.5 \\
Chromone 19 & $3.86 \pm 0.01$ & 48.5 \\
Bar-2 & 57.5 \\
\hline
\end{tabular}

${ }^{1}$ Melting temperature of hPPO with and without tested inhibitors.

Against expectations, no significant activity was observed from the prepared Schiff bases against hPPO. Published works have implied that these compounds could display high affinity for and inhibitory activity against PPOs. Compounds with dihalogenated phenyl cores (e.g., a dichloro-substitution) display inhibitory activity against PPOs and are thus usually used as herbicides. Although the binding docking studies showed that these compounds had a high affinity (absolute value of interaction energy was $7 \mathrm{kcal} / \mathrm{mol}$ or higher (Supplementary Table S2)) for hPPO, incorporation of the Schiff base into the herbicide design led to a loss in inhibitory activity. In this case of BaR-2, the determined value was several times weaker than the published activity against plant mitochondrial PPO2 from N. tabacum. [19].

In vitro inhibition data were further corroborated by a biophysical assay that determined the $\mathrm{T}_{\mathrm{M}}$ of hPPO and hPPO/herbicide complexes (Figure 4, Table 1). Here, upon 
$\mathrm{hPPO}$ binding, the herbicide stabilizes the three-dimensional structure of the protein, resulting in a substantial increase in the $T_{M}$ of the complex. However, compounds that do not inhibit hPPO (e.g., the prepared Schiff bases and chromones, chlortoluron and atrazine) and thus likely do not interact with the enzyme do not show any effect on the $\mathrm{T}_{\mathrm{M}}$ of hPPO. As the ThermoFAD assay is better suited for high-throughput sample processing, it can be used to prescreen putative $\mathrm{hPPO}$ inhibitors before engaging in demanding inhibitory testing that requires more resources.

\section{Melting temperatures}

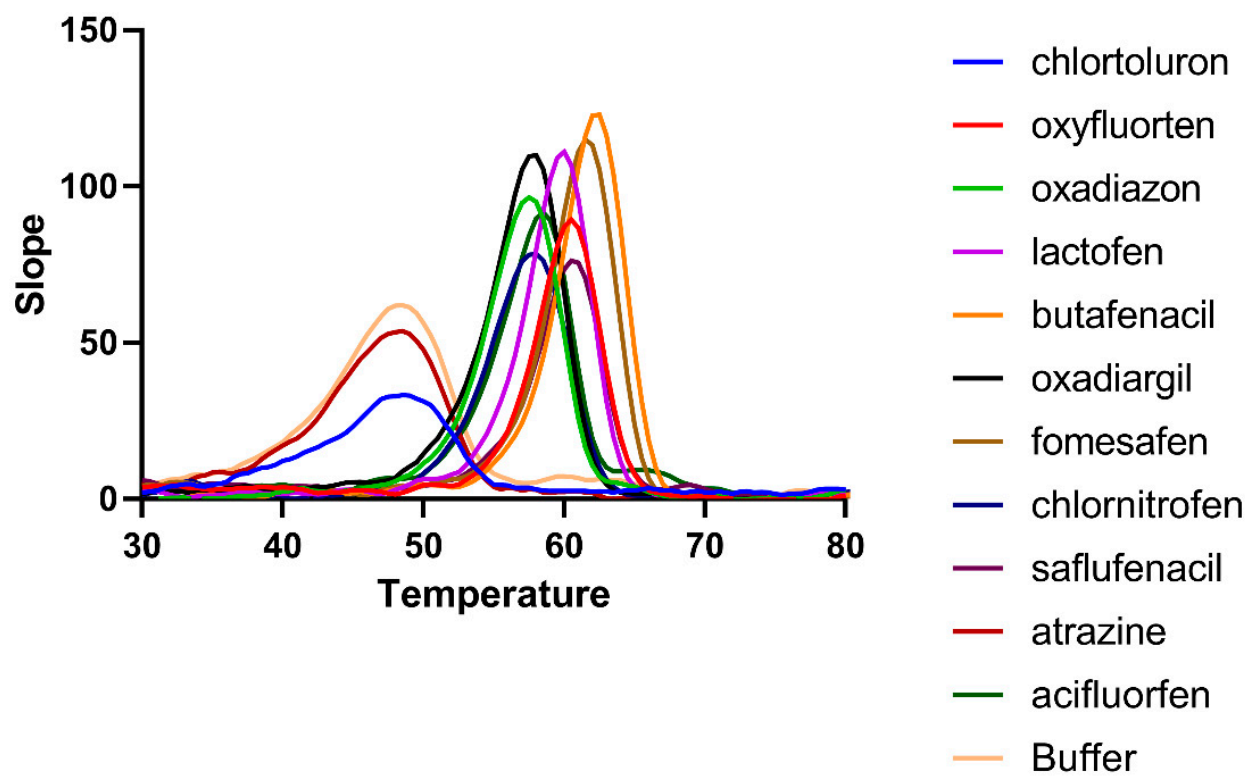

Figure 4. Thermal denaturation profiles of the hPPO complexes. The $\mathrm{T}_{\mathrm{M}}$ values of the hPPO/ herbicide complexes were determined using the ThermoFAD assay, and the peak of the first derivative of the FAD fluorescence represents the $\mathrm{T}_{\mathrm{M}}$ of a given complex.

\subsection{Herbicide Toxicity in Human Cells}

As the tested herbicides inhibit hPPO in the high nanomolar to low micromolar range, we wondered about their toxicity to human cells. To this end, we assayed the viability of human RPMI-8226 lymphoblasts after 2 days of treatment with the herbicides using an MTT assay. Overall, their toxicity to human cells was limited, with half maximal effective concentration $\left(\mathrm{EC}_{50}\right)$ values in the mid-micromolar range (Figure 5). It is interesting to note that cellular toxicity does not strictly correlate with inhibitor affinity for hPPO as determined in vitro. This observation can result from differences in cell permeability and cellular metabolism of the individual compounds and/or possible off-target effects.

\subsection{Homology Modeling}

Our data revealed that the tested herbicides are more potent against Plantae PPOs than the human enzyme. To rationalize these findings, we performed structural alignment of the crystal structures of hPPO (PDB: 3NKS) and ntPPO (PDB: 1SEZ) together with an Arabidopsis thaliana PPO (atPPO) homology model prepared using the SWISS-MODEL server (Figure 6). The most intriguing difference between the inhibitor binding pockets of these orthologues is the substitution of Met-368 (human numbering) in hPPO by Tyr and Phe in atPPO and ntPPO, respectively (Figure 6). The trifluoromethoxy group of acifluorfen, the herbicide co-crystallized with $\mathrm{hPPO}$, is in van der Waals distance from Met368. Substitution at this position with an aromatic amino acid (present in both atPPO and ntPPO) by Met-368 in the human enzyme leads to the disruption of the original $\pi-\pi$ stacking interactions, which likely results in lower inhibitor potency for the human orthologue. 


\section{RPMI-8226 viability}

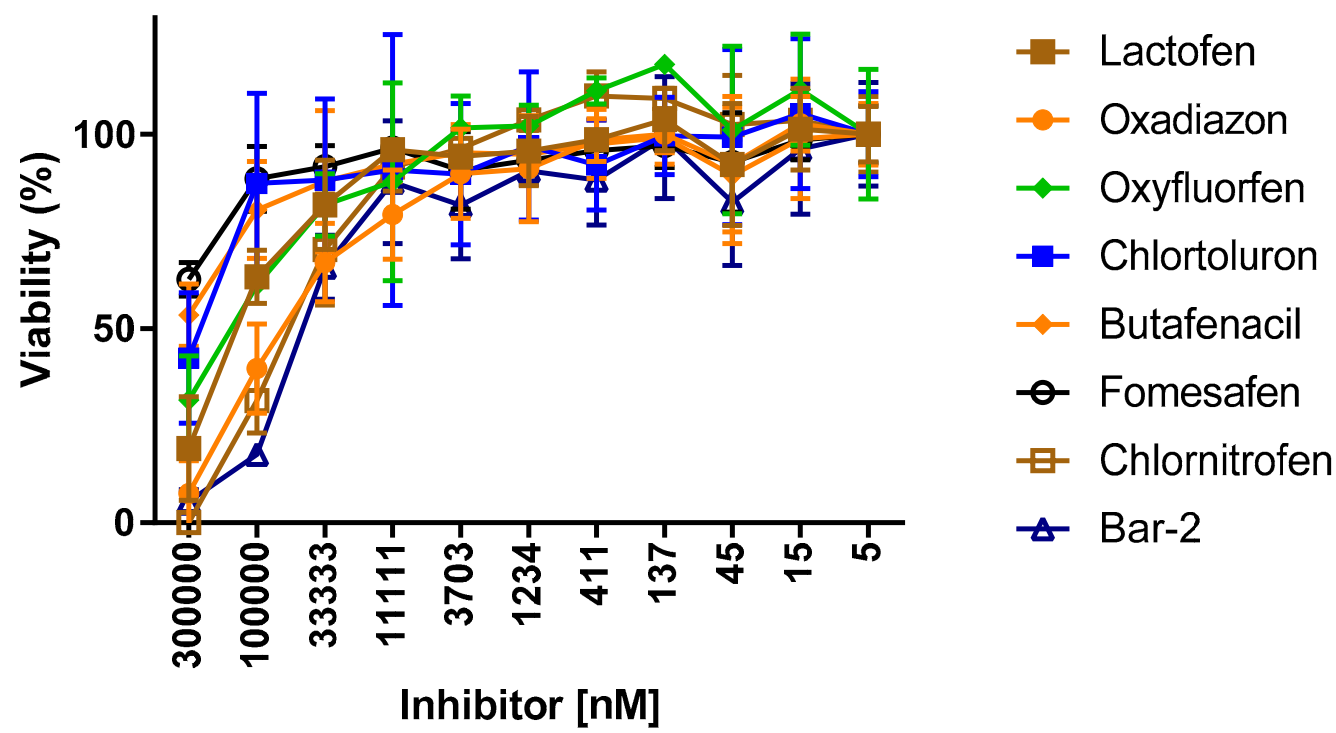

Figure 5. Cytotoxicity of the tested herbicides. Cells were treated with varying concentrations of herbicides for $48 \mathrm{~h}$, and cell viability was determined using the MTT assay.

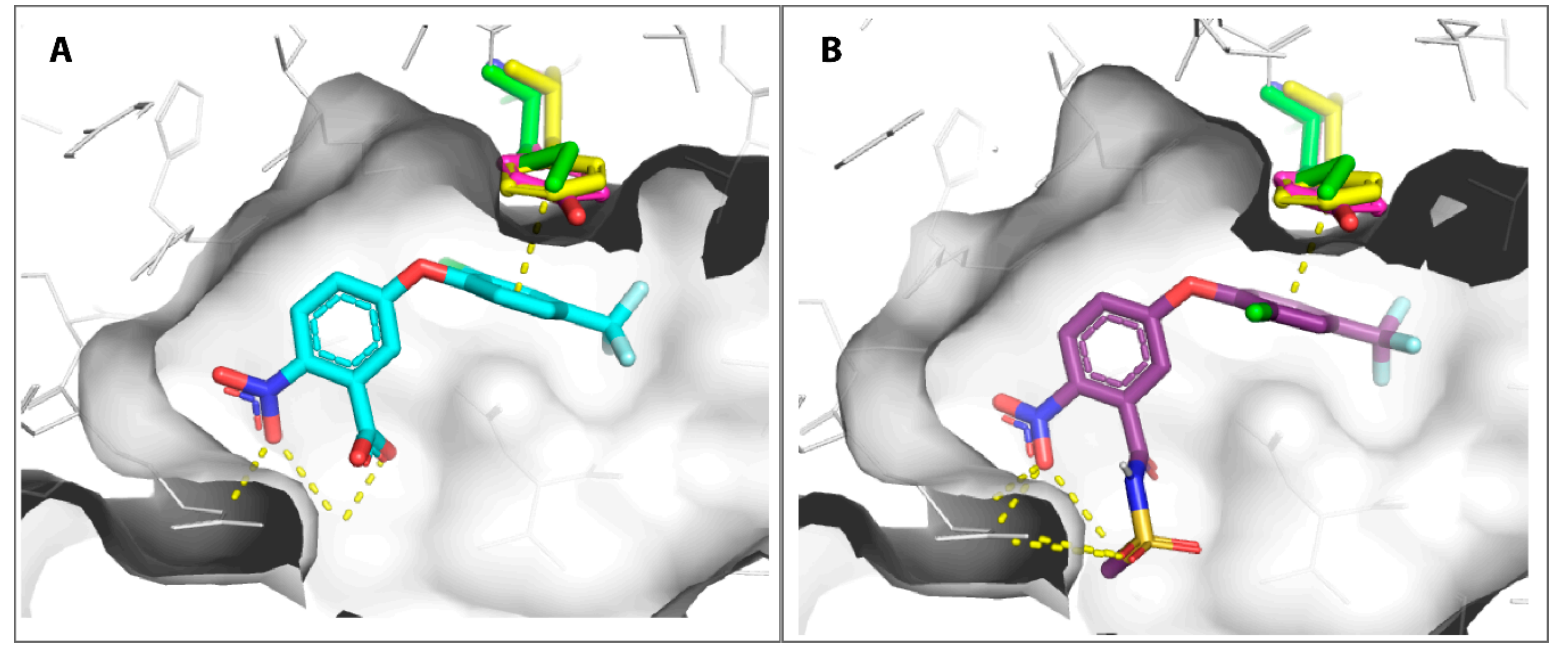

Figure 6. Methionine substitution is linked to the lower potency of herbicides against hPPO. The hPPO binding pocket shown in grey representation (A) co-crystallized with acifluorfen (stick representation, cyan carbon atoms) and (B) docked with fomesafen (stick representation, violet carbon atoms). hPPO Met-368 is highlighted by green sticks. The atPPO and ntPPO structures were superimposed onto hPPO, but only the corresponding Tyr (stick representation, magenta carbon atoms) and Phe (stick representation, yellow carbon atoms) are highlighted.

As there were no crystal structures of hPPO with herbicides used in this study, we were interested in whether the tested compounds share the same binding mode as acifluorfen and would therefore act on human and plant PPOs in a similar manner. To this end, we selected fomesafen a representative compound, which displayed the most potent hPPO inhibition, and docked it into hPPO. The docking experiment result, as depicted in Figure 6B, points towards a similar binding orientation of both herbicides. We thus hypothesize that all herbicides of this chemotype act similarly and that the Met-368 substitution is responsible for their lower potency against hPPO. 


\section{Discussion}

Based on the obtained results, the combination of nitrophenyl and trifluoromethylbenzyl represents the structural motif of a potent inhibitor of hPPO. Docking and crystallographic studies of PPO from Myxococcus xanthus showed an acifluorfen water-mediated interaction with the carbonyl oxygen of Val-164 via its carboxylate groups [29]. Based on these results, we can expect that loss of a negative charge will lead to repression or loss of interaction. Nevertheless, lactofen and oxyfluorten displayed opposite behaviors.

Lactofen, whose carboxy group is a substituted ethyl ester of lactic acid, sometimes displayed a lower $\mathrm{IC}_{50}$ value $(0.33 \mu \mathrm{M})$ than acifluorfen $\left(\mathrm{IC}_{50}=1.48 \mu \mathrm{M}\right)$. Oxyfluorten and fomesafen are potent $\mathrm{hPPO}$ inhibitors ( $\mathrm{IC}_{50}=0.13$ and $0.11 \mu \mathrm{M}$, respectively), which implies that stabilization of the hPPO-inhibitor complex could also be supported by this methyl group. In this case of lactofen, its effect is probably limited by steric factors due to substituent residue. Nevertheless, the docking study implied that the combination of nitrogen and thionyl groups can be a prospective structural motif for this interaction. Lactofen has two carbonyl groups, which can also participate in interactions with the valine carbonyl group. However, the oxyfluorten ethoxy group, on the other hand, can be an attractive binding partner for hydrophobic amino acids such as VAL.

In accordance with this proposed model, chlornitrofen lost inhibition activity against hPPO. This implies that the contribution of only the nitrogen group can be enough for binding to the valine carbonyl group. Therefore, we hypothesized that hPPO resistance against chlornitrofen is mainly due to the loss of the carboxy group. Nevertheless, the mechanism of the acifluorfen interaction with PPO is intercalation of the 2-chloro-4trifluoromethylphenoxy into Met-365 and Gly-167. However, in the case of hPPO, Tyr and Phe are instead in proximity (Figure 6). The difference most probably leads to a decrease in the inhibitory activity of the tested herbicides.

On the other hand, targeting of these Tyr and Phe residues could be a promising idea in the design of hPPO inhibitors. Suitable structural motifs should have more aromatic characteristics (stronger binding to the aromatic parts of Tyr and Phe via $\pi-\pi$ interactions) and the ability to form hydrogen bonds to support interactions with the phenol group of Tyr. This could be solved by incorporating the 2-hydroxyaryl moiety of the Schiff bases into inhibitor design [48,49]. In addition, their structural motifs enable binding to Arg groups [27], thereby potentially supporting the inhibition of its activity [29]. The basic design of the prepared hPPO inhibitors is shown in Figure 7.
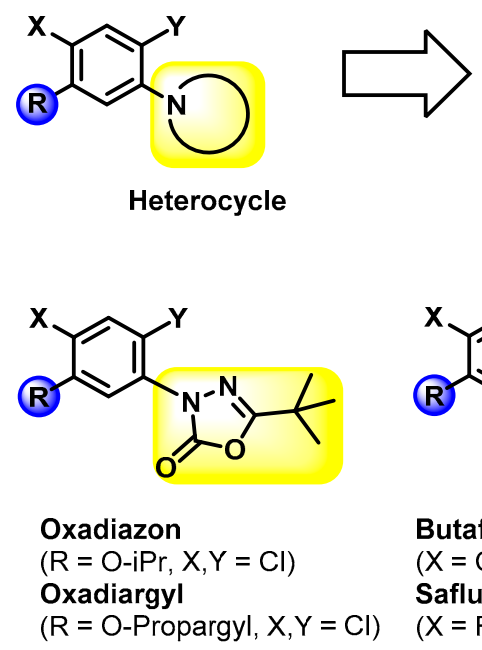

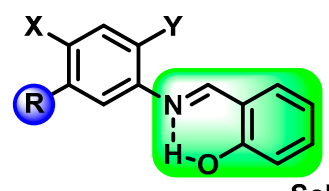

Schiff base

$X, Y=$ electron-withdrawing lipophilic group $(\mathrm{F}, \mathrm{Cl}, \mathrm{Br}, \mathrm{CN})$ $\mathbf{R}=$ O-alkyl, COOAlkyl, (hetero)aryl

Figure 7. Design of Prepared Synthetic hPPO Inhibitors.

However, none of the synthetic inhibitors displayed any significant inhibitory activity. This fact could be explained by the loss of the nitro substitution. However, butafenacil, saflufenacil, oxadiargyl, oxadiazon and Bar-2 did not have this functional group and are potent hPPO inhibitors. Due to the variability of the aliphatic substitution of herbicides 
with inhibition activity for hPPO, aliphatic parts of synthetic compounds could be enabled to bind to hPPO. Most likely, in our opinion, the corresponding part of the enzyme active site is narrow and rigid for intercalation of the hydroxyaryl moiety of synthetic inhibitors.

Based on the determined $\mathrm{IC}_{50}$ values, fomesafen should be the most toxic of the tested inhibitors. However, the toxicity of the tested herbicides to lymphoblasts did not correlate with their inhibitory activity against hPPO. It is possible that a significant part of their toxic effects in vitro cannot be associated with hPPO inhibition, such as coproporphyrin accumulation [13]. Krijit et al. reported that after herbicide dosage, liver, fecal and bile porphyrin IX accumulation increased in the following order: fomesafen, oxyfluorfen and oxadiazon [50]. However, based on our results, we would expect the opposite trend.

This result implies that other phenomena, such as cellular uptake and herbicide transport in the blood, can play a role in the physiological effects of these compounds. For example, Dong et al. observed that fomesafen can form a complex with serum albumin [51]. Serum albumin is a long-circulating and highly abundant protein $(40 \mathrm{mg} / \mathrm{mL})$ [52]. Transported agents have a longer half-life than their free form in the blood and thereby lower cellular uptake. On the other hand, serum albumin has been intensively studied as a carrier for the targeted transport of anticancer agents, and PPO inhibition can significantly increase the effects of photodynamic therapy.

Although we did not design new synthetic inhibitors of hPPO, based on the structural motifs of the tested herbicides (mainly fomesafen), we found prospective structural motifs as starting points for redesign. Based on docking studies, we found that commercial herbicides interact with the carbonyl group of valine and their close surroundings (e.g., carboxy, ester and ether groups) and Met-365 (e.g., halogenated, mostly fluorinated aromatic groups of herbicides). The obtained information could also be used to design new synthetic inhibitors to better predict the toxicity of commercial PPO herbicides.

\section{Conclusions}

Compounds with Schiff base structural motifs (9-13 and 17-19) were prepared and characterized by ${ }^{1} \mathrm{H}$ NMR, ${ }^{13} \mathrm{C}$ NMR and mass spectroscopy (MS). The inhibition activity of these compounds and of PPO herbicides and the influence of these compounds on the $h P P O T_{M}$ were determined by a protoporphyrin IX fluorescence assay and the ThermoFAD assay, respectively. Some commercial herbicides, such as fomesafen, displayed strong inhibition of hPPO activity. In the case of Schiff bases 9-13 and chromones 17-19, no significant inhibitory activity was observed. However, we discovered the hPPO binding model with inhibitors based on a docking study (by using AutoDock Vina software) and determined the $\mathrm{IC}_{50}$ values for their redesign and participation in the accurate prediction of the toxicity of PPO herbicides.

Supplementary Materials: The following are available online at https://www.mdpi.com/2227-971 7/9/2/383/s1, Figures S1-S10: ${ }^{1} \mathrm{H}$ and ${ }^{13} \mathrm{C}$ NMR spectra of compounds $\mathbf{2}$ and 3, Schiff bases $\mathbf{9 - 1 3}$ and chromones 17-19. Figure S11: Re-docking of acifluorfen into the binding pocket of hPPO (PDB: 3NKS). Table S1: Calculated interaction energy for hPPO and tobacco PPO. Table S2: Influence of PPO herbicides on the activity of plant PPOs.

Author Contributions: Conceptualization, project administration and funding were achieved by P.M. Original draft preparation and supervision of the manuscript were performed by M.J. Writing, discussion and introduction, and design of the synthetic inhibitors were performed by M.M. MS and ${ }^{1} \mathrm{H}$ and ${ }^{13} \mathrm{C}$ NMR analyses of prepared synthetic inhibitors were performed by K.V. Synthesis of BAR-2 and compounds $\mathbf{2}$ and $\mathbf{3}$ was performed by T.B. Synthesis of Schiff bases $\mathbf{9 - 1 3}$ was performed by R.K. Preparation of chromones 17-19 was performed by N.A. All authors have read and agreed to the published version of the manuscript.

Funding: This research was funded by the Czech Health Research Council (grant No 17-32727A) and the CAS (RVO: 86652036).

Institutional Review Board Statement: Not applicable.

Informed Consent Statement: Not applicable. 
Data Availability Statement: Data is contained within the article and supplementary material.

Acknowledgments: We would like to thank Zsofia Kutil, Marketa Gresova and Cyril Bařinka for determination of the herbicide properties (IC50, TM values and cytotoxicity) and enzyme docking.

Conflicts of Interest: The authors declare no conflict of interest. The funders had no role in the design of the study; in the collection, analyses, or interpretation of data; in the writing of the manuscript; or in the decision to publish the results.

\section{References}

1. Singal, A.K.; Anderson, K.E. Variegate Porphyria. In Gene Reviews ${ }^{\circledR}$ [Internet]; Adam, M.P., Ardinger, H.H., Pagon, R.A., Wallace, S.E., Bean, L.J.H., Stephens, K., Amemiya, A., Eds.; University of Washington: Seattle, WA, USA, 1993-2021. [PubMed]

2. Kirsch, R.; Meissner, P.; Hift, R. Variegate Porphyria. Semin. Liver Dis. 1998, 18, 33-41. [CrossRef]

3. Frank, J.; Lam, H.; Zaider, E.; Poh-Fitzpatrick, M.; Christiano, A.M. Molecular basis of variegate porphyria: A missense mutation in the protoporphyrinogen oxidase gene. J. Med Genet. 1998, 35, 244-247. [CrossRef] [PubMed]

4. A Dailey, H.; A Dailey, T. Characteristics of human protoporphyrinogen oxidase in controls and variegate porphyrias. Cell. Mol. Biol. 1997, 43, 67-73.

5. Frank, J.; McGrath, J.A.; Poh-Fitzpatrick, M.B.; Hawk, J.L.; Christiano, A.M. Mutations in the translation initiation codon of the protoporphyrinogen oxidase gene underlie variegate porphyria. Clin. Exp. Dermatol. 1999, 24, 296-301. [CrossRef] [PubMed]

6. Peoc'H, K.; Manceau, H.; Karim, Z.; Wahlin, S.; Gouya, L.; Puy, H.; Deybach, J.-C. Hepatocellular carcinoma in acute hepatic porphyrias: A Damocles Sword. Mol. Genet. Metab. 2019, 128, 236-241. [CrossRef] [PubMed]

7. Aminaka, M.; Kondo, M.; Takata, A.; Yamauchi, H.; Ikeda, M.; Yoshida, K. Oxidative stress in porphyria and carriers. Nihon Eiseigaku Zasshi. 2008, 63, 628-635. [CrossRef] [PubMed]

8. Luvai, A.; Mbagaya, W.; Narayanan, D.; Degg, T.; Toogood, G.; I Wyatt, J.; Swinson, D.; Hall, C.J.; Barth, J.H. Hepatocellular carcinoma in variegate porphyria: A case report and literature review. Ann. Clin. Biochem. Int. J. Lab. Med. 2015, 52, 407-412. [CrossRef] [PubMed]

9. Krijt, J.; Stránská, P.; Sanitraák, J.; Chlumská, A.; Fakan, F. Liver preneoplastic changes in mice treated with the herbicide fomesafen. Hum. Exp. Toxicol. 1999, 18, 338-344. [CrossRef]

10. Alexandre, S.; Rast, C.; Maire, M.; Orfila, L.; Vasseur, P. $\mathrm{ZnCl}_{2}$ induces Syrian hamster embryo (SHE) cell transformation. Toxicol. Lett. 2003, 142, 77-87. [CrossRef]

11. Theodoridis, G.; Liebl, R.; Zagar, C. Protoporphyrinogen IX Oxidase Inhibitors. In Modern Crop Protection Compounds; Wiley-VCH Verlag GmbH Co. KGaA: Weinheim, Germany, 2012; pp. 178-181.

12. Shepherd, M.; Dailey, H.A. A continuous fluorimetric assay for protoporphyrinogen oxidase by monitoring porphyrin accumulation. Anal. Biochem. 2005, 344, 115-121. [CrossRef]

13. Jacobs, J.M.; Sinclair, P.R.; Gorman, N.; Jacobs, N.J.; Sinclair, J.F.; Bement, W.J.; Walton, H. Effects of diphenyl ether herbicides on porphyrin accumulation by cultured hepatocytes. J. Biochem. Toxicol. 1992, 7, 87-95. [CrossRef] [PubMed]

14. Leet, J.K.; Hipszer, R.A.; Volz, D.C. Butafenacil: A positive control for identifying anemia- and variegate porphyria-inducing chemicals. Toxicol. Rep. 2015, 2, 976-983. [CrossRef]

15. Leet, J.K.; Lindberg, C.D.; Bassett, L.A.; Isales, G.M.; Yozzo, K.L.; Raftery, T.D.; Volz, D.C. High-Content Screening in Zebrafish Embryos Identifies Butafenacil as a Potent Inducer of Anemia. PLoS ONE 2014, 9, e104190. [CrossRef]

16. Xu, Z.; Ni, H.; Huang, Y.; Meng, Y.; Cao, Z.; Liao, X.; Zhang, S.; Guo, X.; Lu, H. Effect of fomesafen on the embryonic development of zebrafish. Chemosphere 2020, 259, 127380. [CrossRef] [PubMed]

17. Krijt, J.; Psenák, O.; Vokurka, M.; Chlumská, A.; Fakan, F. Experimental hepatic uroporphyria induced by the diphenyl-ether herbicide fomesafen in male DBA/2 mice. Toxicol. Appl. Pharmacol. 2003, 189, 28-38. [CrossRef]

18. Krijt, J.; Vokurka, M.; Sanitrák, J.; Janoušek, V.; Van Holsteijn, L.; Blaauboer, B. Effect of the protoporphyrinogen oxidase-inhibiting herbicide fomesafen on liver uroporphyrin and heptacarboxylic porphyrin in two mouse strains. Food Chem. Toxicol. 1994, 32, 641-650. [CrossRef]

19. Wang, D.-W.; Zhang, R.-B.; Yu, S.-Y.; Liang, L.; Ismail, I.; Li, Y.-H.; Xu, H.; Wen, X.; Xi, Z. Discovery of Novel NIsoxazolinylphenyltriazinones as Promising Protoporphyrinogen IX Oxidase Inhibitors. J. Agric. Food Chem. 2019, 67, 12382-12392. [CrossRef]

20. Bazzocco, S.; Dopeso, H.; Carton-Garcia, F.; Macaya, I.; Andretta, E.; Chionh, F.; Rodrigues, P.; Garrido, M.; Alazzouzi, H.; Nieto, R.; et al. Highly Expressed Genes in Rapidly Proliferating Tumor Cells as New Targets for Colorectal Cancer Treatment. Clin. Cancer Res. 2015, 21, 3695-3704. [CrossRef]

21. Kurumi, H.; Kanda, T.; Kawaguchi, K.; Yashima, K.; Koda, H.; Ogihara, K.; Matsushima, K.; Nakao, K.; Saito, H.; Fujiwara, Y.; et al. Protoporphyrinogen oxidase is involved in the fluorescence intensity of 5-aminolevulinic acid-mediated laser-based photodynamic endoscopic diagnosis for early gastric cancer. Photodiagnosis Photodyn. Ther. 2018, 22, 79-85. [CrossRef]

22. Carre, J.; Eleouet, S.; Rousset, N.; Vonarx, V.; Heyman, D.; Lajat, Y.; Patrice, T. Protoporphyrin IX fluorescence kinetics in C6 glioblastoma cells after delta-aminolevulinic acid incubation: Effect of a protoporphyrinogen oxidase inhibitor. Cell. Mol. Biol. 1999, 45, 433-444. [PubMed] 
23. Fingar, V.H.; Wieman, T.J.; McMahon, K.S.; Haydon, P.S.; Halling, B.P.; Yuhas, D.A.; Winkelman, J.W. Photodynamic thera-py using a protoporphyrinogen oxidase inhibitor. Cancer Res. 1997, 57, 4551-4556.

24. Malekshah, R.E.; Fahimirad, B.; Aallaei, M.; Khaleghian, A. Synthesis and toxicity assessment of $\mathrm{Fe}_{3} \mathrm{O}_{4} \mathrm{NPs}_{\mathrm{s}}$ grafted by $\sim$ $\mathrm{NH}_{2}$-Schiff base as anticancer drug: Modeling and proposed molecular mechanism through docking and molecular dynamic simulation. Drug Deliv. 2020, 27, 1201-1217. [CrossRef] [PubMed]

25. Al Rasheed, H.H.; Malebari, A.M.; Dahlous, K.A.; Fayne, D.; El-Faham, A. Synthesis, Anti-proliferative Activity, and Molecular Docking Study of New Series of 1,3-5-Triazine Schiff Base Derivatives. Molecules 2020, 25, 4065. [CrossRef]

26. Lv, J.-J.; Song, W.-T.; Li, X.-M.; Gao, J.-M.; Yuan, Z.-L. Synthesis of a New Phenyl Chlormethine-Quinazoline Derivative, a Potential Anti-Cancer Agent, Induced Apoptosis in Hepatocellular Carcinoma Through Mediating Sirt1/Caspase 3 Signaling Pathway. Front. Pharmacol. 2020, 11, 911. [CrossRef] [PubMed]

27. Shang, X.; Li, J.; Guo, K.; Ti, T.; Wang, T.; Zhang, J. Development and cytotoxicity of Schiff base derivative as a fluorescence probe for the detection of 1-Arginine. J. Mol. Struct. 2017, 1134, 369-373. [CrossRef]

28. Koch, M.; Breithaupt, C.; Kiefersauer, R.; Freigang, J.; Huber, R.; Messerschmidt, A. Crystal structure of protoporphyrinogen IX oxidase: A key enzyme in haem and chlorophyll biosynthesis. EMBO J. 2004, 23, 1720-1728. [CrossRef] [PubMed]

29. Corradi, H.R.; Corrigall, A.V.; Boix, E.; Mohan, C.G.; Sturrock, E.D.; Meissner, P.N.; Acharya, K.R. Crystal Structure of Protoporphyrinogen Oxidase from Myxococcus xanthus and Its Complex with the Inhibitor Acifluorfen. J. Biol. Chem. 2006, 281, 38625-38633. [CrossRef] [PubMed]

30. Mirjalili, S.; Dejamfekr, M.; Moshtaghian, A.; Salehi, M.; Behzad, M.; Khaleghian, A. Induction of Cell Cycle Arrest in MKN45 Cells after Schiff Base Oxovanadium Complex Treatment Using Changes in Gene Expression of CdC25 and P53. Drug Res. 2020, 70,545-551. [CrossRef]

31. Kaur, P.; Johnson, A.; Northcote-Smith, J.; Lu, C.; Suntharalingam, K. Immunogenic Cell Death of Breast Cancer Stem Cells Induced by an Endoplasmic Reticulum-Targeting Copper(II) Complex. ChemBioChem 2020, 21, 3618-3624. [CrossRef] [PubMed]

32. Shi, S.; Yu, S.; Quan, L.; Mansoor, M.; Chen, Z.; Hu, H.; Liu, D.; Liang, Y.; Liang, F. Synthesis and antitumor activities of transition metal complexes of a bis-Schiff base of 2-hydroxy-1-naphthalenecarboxaldehyde. J. Inorg. Biochem. 2020, 210, 111173. [CrossRef]

33. Bao, R.-D.; Song, X.-Q.; Kong, Y.-J.; Li, F.-F.; Liao, W.-H.; Zhou, J.; Zhang, J.-H.; Zhao, Q.-H.; Xu, J.-Y.; Chen, C.-S.; et al. A new Schiff base copper(II) complex induces cancer cell growth inhibition and apoptosis by multiple mechanisms. J. Inorg. Biochem. 2020, 208, 111103. [CrossRef]

34. Dailey, H.A.; Dailey, T.A. Protoporphyrinogen Oxidase of Myxococcus xanthus. J. Biol. Chem. 1996, 271, 8714-8718. [CrossRef]

35. Thomsen, C.; Sørensen, P.O.; Egebjerg, J. 1-(3-(9H-Carbazol-9-yl)-1-propyl)-4-(2-methoxyphenyl)-4-piperidinol, a novel subtype selective inhibitor of the mouse type II GABA-transporter. Br. J. Pharmacol. 1997, 120, 983-985. [CrossRef]

36. Trott, O.; Olson, A.J. AutoDock Vina: Improving the speed and accuracy of docking with a new scoring function, efficient optimization, and multithreading. J. Comput. Chem. 2010, 31, 455-461. [CrossRef] [PubMed]

37. Qin, X.; Tan, Y.; Wang, L.; Wang, Z.; Wang, B.; Wen, X.; Yang, G.; Xi, Z.; Shen, Y. Structural insight into human variegate porphyria disease. FASEB J. 2010, 25, 653-664. [CrossRef]

38. Long, F.; Nicholls, R.A.; Emsley, P.; Gražulis, S.; Merkys, A.; Vaitkus, A.; Murshudov, G.N. AceDRG: A stereochemical description generator for ligands. Acta Crystallogr. Sect. D Struct. Biol. 2017, 73, 112-122. [CrossRef]

39. He, N.; Liu, P.; Wang, Z.; Guo, Z.; Yan, X.; Chen, H.; Zhang, Z. Discovery of selective Mcl-1 inhibitors via structure-based design and structure-activity relationship analysis. Biochem. Biophys. Res. Commun. 2019, 512, 921-926. [CrossRef]

40. Forneris, F.; Orrù, R.; Bonivento, D.; Chiarelli, L.R.; Mattevi, A. ThermoFAD, aThermofluor ${ }^{\circledR}$-adapted flavinad hocdetection system for protein folding and ligand binding. FEBS J. 2009, 276, 2833-2840. [CrossRef] [PubMed]

41. El-Shaaer, H.M.; Foltínová, P.; Lácová, M.; Chovancová, J.; Stankovičová, H. Synthesis, antimicrobial activity and bleaching effect of some reaction products of 4-oxo-4H-benzopyran-3-carboxaldehydes with aminobenzothiazoles and hydrazides. Il Farm. 1998, 53, 224-232. [CrossRef]

42. Dziewulska-Kułaczkowska, A.; Mazur, L. Structural studies and characterization of 3-formylchromone and products of its reactions with chosen primary aromatic amines. J. Mol. Struct. 2011, 985, 233-242. [CrossRef]

43. Jakubek, M.; Kejík, Z.; Parchaňský, V.; Kaplánek, R.; Vasina, L.; Martásek, P.; Král, V. Water soluble chromone Schiff base derivatives as fluorescence receptor for aluminium(III). Supramol. Chem. 2016, 29, 1-7. [CrossRef]

44. Park, J.; Ahn, Y.O.; Nam, J.-W.; Hong, M.-K.; Song, N.; Kim, T.; Yu, G.-H.; Sung, S.-K. Biochemical and physiological mode of action of tiafenacil, a new protoporphyrinogen IX oxidase-inhibiting herbicide. Pestic. Biochem. Physiol. 2018, 152, 38-44. [CrossRef]

45. Dayan, F.E.; Daga, P.R.; Duke, S.O.; Lee, R.M.; Tranel, P.J.; Doerksen, R.J. Biochemical and structural consequences of a glycine deletion in the $\alpha-8$ helix of protoporphyrinogen oxidase. Biochim. Biophys. Acta (BBA) Proteins Proteom. 2010, 1804, $1548-1556$. [CrossRef] [PubMed]

46. Grossmann, K.; Hutzler, J.; Caspar, G.; Kwiatkowski, J.; Brommer, C.L. Saflufenacil (Kixor ${ }^{\mathrm{TM}}$ ): Biokinetic Properties and Mechanism of Selectivity of a New Protoporphyrinogen IX Oxidase Inhibiting Herbicide. Weed Sci. 2011, 59, 290-298. [CrossRef]

47. Bi, B.; Wang, Q.; Coleman, J.J.; Porri, A.; Peppers, J.M.; Patel, J.D.; Betz, M.; Lerchl, J.; McElroy, J.S. A novel mutation A212T in chloroplast Protoporphyrinogen oxidase (PPO1) confers resistance to PPO inhibitor Oxadiazon inEleusine indica. Pest Manag. Sci. 2020, 76, 1786-1794. [CrossRef]

48. Park, M.; Kim, Y. Schiff base receptor for salicylaldehyde and barbituric acid. Thin Solid Films 2000, 363, 156-159. [CrossRef] 
49. Sobczyk, L.; Chudoba, D.; Tolstoy, P.M.; Filarowski, A. Some Brief Notes on Theoretical and Experimental Investigations of Intramolecular Hydrogen Bonding. Molecules 2016, 21, 1657. [CrossRef]

50. Krijt, J.; Vokurka, M.; Sanitrák, J.; Janousek, V. Effect of Protoporphyrinogen Oxidase Inhibitors on Mammalian Porphyrin Metabolism. In ACS Symposium Series; American Chemical Society (ACS): Washington, DC, USA, 1994; Volume 559, pp. $247-254$.

51. Dong, X.; Wang, L.; Feng, R.; Ren, Z.; Zhang, L.; Lu, H. Insights into the binding mechanism of a model protein with fomesafen: Spectroscopic studies, thermodynamics and molecular modeling exploration. J. Mol. Struct. 2019, 1195, 892-903. [CrossRef]

52. Hoogenboezem, E.N.; Duvall, C.L. Harnessing albumin as a carrier for cancer therapies. Adv. Drug Deliv. Rev. 2018, 130, 73-89. [CrossRef] 